\title{
Upper ocean mixing controls the seasonality of planktonic foraminifer fluxes and associated strength of the carbonate pump in the oligotrophic North Atlantic
}

\author{
K. H. Salmon ${ }^{1}$, P. Anand ${ }^{1}$, P. F. Sexton ${ }^{1}$, and M. Conte ${ }^{2}$ \\ ${ }^{1}$ Environment, Earth and Ecosystems, The Open University, UK \\ ${ }^{2}$ Bermuda Institute of Ocean Sciences, St George's GE01, Bermuda \\ Correspondence to: K. H. Salmon (kate.salmon@open.ac.uk)
}

Received: 23 July 2014 - Published in Biogeosciences Discuss.: 12 August 2014

Revised: 5 December 2014 - Accepted: 11 December 2014 - Published: 13 January 2015

\begin{abstract}
Oligotrophic regions represent up to $75 \%$ of Earth's open-ocean environments. They are thus areas of major importance in understanding the plankton community dynamics and biogeochemical fluxes. Here we present fluxes of total planktonic foraminifera and 11 planktonic foraminifer species measured at the Oceanic Flux Program (OFP) time series site in the oligotrophic Sargasso Sea, subtropical western North Atlantic Ocean. Foraminifera flux was measured at $1500 \mathrm{~m}$ water depth, over two $\sim 2.5$-year intervals: 1998-2000 and 2007-2010. We find that foraminifera flux was closely correlated with total mass flux, carbonate and organic carbon fluxes. We show that the planktonic foraminifera flux increases approximately 5-fold during the winter-spring, contributing up to $\sim 40 \%$ of the total carbonate flux. This was primarily driven by increased fluxes of deeper-dwelling globorotaliid species, which contributed up to $90 \%$ of the foraminiferal-derived carbonate during late winter-early spring. Interannual variability in total foraminifera flux, and in particular fluxes of the deepdwelling species (Globorotalia truncatulinoides, Globorotalia hirsuta and Globorotalia inflata), was related to differences in seasonal mixed layer dynamics affecting the strength of the spring phytoplankton bloom and export flux, and by the passage of mesoscale eddies. As these heavily calcified, dense carbonate tests of deeper-dwelling species (3 times denser than surface dwellers) have greater sinking rates, this implies a high seasonality of the biological carbonate pump in oligotrophic oceanic regions. Our data suggest that climate cycles, such as the North Atlantic Oscillation, which modulates nutrient supply into the euphotic
\end{abstract}

zone and the strength of the spring bloom, may also in turn modulate the production and flux of these heavily calcified deep-dwelling foraminifera by increasing their food supply, thereby intensifying the biological carbonate pump.

\section{Introduction}

Planktonic foraminifera (PF) comprise $23-56 \%$ of the total open marine calcite flux and thus exert an important control on global carbon cycling (Schiebel, 2002). They are used extensively in palaeoceanographic and palaeoclimatic reconstructions via utilisation of their species abundance and assemblage composition (e.g. Lutz, 2011; Sexton and Norris, 2011), geochemical signatures (e.g. Zeebe et al., 2008), shell mass (e.g. Barker and Elderfield, 2002) and in evolutionary and biogeographic studies (e.g. Sexton and Norris, 2008). However, gaps remain in our understanding of the controls on their spatial and temporal distribution in the upper water column. Following the early 1980s when sea surface temperatures (SSTs) were thought to dominantly control PF distributions and abundance (CLIMAP project members, 1994), a number of other environmental parameters have also been shown to exert influence on the distribution and abundance of PF, such as salinity (Kuroyanagi and Kawahata, 2004), productivity, nutrient availability (Schiebel, 2002; Northcote and Neil, 2005; Žarić et al., 2005; Storz et al., 2009; Sexton and Norris, 2011) and water column stability (Hemleben et al., 1989; Lohmann and Schweitzer, 1990; King and Howard, 2003). It is thus imperative to better understand the 
environmental factors controlling modern-day PF abundance in order to produce accurate interpretations of palaeorecords based on PF assemblages.

The response of PF flux and species composition to environmental and/or oceanographic factors have been studied using plankton tow materials which can give information about living populations' species distribution and depth habitats within the upper ocean (Tolderlund and Be; 1971, Fairbanks et al., 1980; Schiebel, 2002). However, temporal resolution is often limited when using plankton tows. The continuous time series records provided by sediment traps allow a more complete understanding of the seasonal and interannual changes in PF flux and can aid in integrating living assemblages with the sedimentary record.

Earlier studies of planktonic foraminifer flux off Bermuda at the Seasonal Changes in Foraminifera Flux (SCIFF) site (Fig. 1) (Deuser et al., 1981; Hemleben et al., 1985; Deuser, 1987; Deuser and Ross, 1989) were based on a bimonthly sampling interval and provide a general description of foraminifera flux, species composition and seasonality. These studies found that $\mathrm{PF}>125 \mu \mathrm{m}$ comprise on average $22 \%$ of the total calcium carbonate flux in the Sargasso Sea (Deuser and Ross, 1989), although this average underestimates the importance of the PF flux contribution during different seasons. Here we utilise a higher resolution bi-weekly sediment trap time series from the Oceanic Flux Program (OFP), ideal for studying the detailed response of PF species flux to physical oceanographic changes because PF species lifespan is approximately 2-3 weeks (Spero, 1998; Erez et al., 1991). These samples also benefit from the availability of upper ocean hydrographic and biogeochemical data collected at the nearby Bermuda Atlantic Time Series (BATS) site, as well as remote sensing data, which allows us to evaluate the environmental factors that control the total foraminifer flux as well as the response of individual species flux. Furthermore, we assess the relative contribution of PF flux to regional carbonate export and explore the implications of our findings for carbonate cycling in the oligotrophic North Atlantic.

\section{Oceanographic setting}

The Sargasso Sea is located within the North Atlantic gyre, which is characterised by high temperatures and salinities, and weak, variable surface currents (Lomas et al., 2013, and references therein). The OFP and BATS sites are situated in a transition region between the northern eutrophic waters and the relatively oligotrophic subtropical convergence zone in the south (Steinberg et al., 2001, and references therein). Subtropical Mode Water (STMW) forms on the fringes, north of the gyre, owing to convective deep winter mixing and entrainment of nutrients and is characterized by temperatures of $17.8-18.4^{\circ} \mathrm{C}$ and salinities of $\sim 36.5 \pm 0.05$

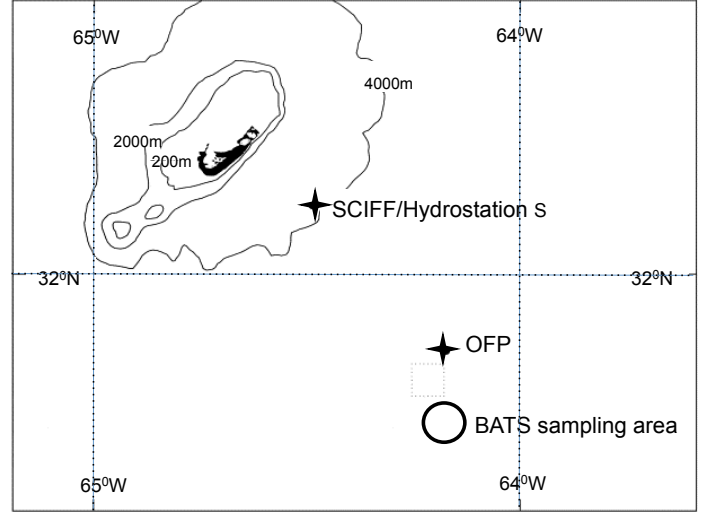

Figure 1. Map to show locations of the Oceanic Flux Program (OFP) mooring $\left(31^{\circ} 50^{\prime} \mathrm{N}, 64^{\circ} 10^{\prime} \mathrm{W}\right)$ and the Bermuda Atlantic Time Series (BATS) hydrographic station $\left(31^{\circ} 40^{\prime} \mathrm{N}, 64^{\circ} 10^{\prime} \mathrm{W}\right)$ and Seasonal Changes in Foraminifera Flux (SCIFF) site and Hydrostation $\mathrm{S}$ in relation to Bermuda.

(Bates et al., 2002), typically occurring between $\sim 250$ and $400 \mathrm{~m}$ water depth (Bates, 2007).

The hydrography and biogeochemistry of the area have been summarised by Michaels and Knap (1996), Steinberg et al. (2001), Lomas et al. (2013) and references therein. In the absence of large changes in salinity, the $10^{\circ} \mathrm{C}$ seasonal change in surface temperatures driven by solar insolation controls the shoaling and erosion of the mixed layer, which reaches a maximum of $250-400 \mathrm{~m}$ in late winter, increasing vertical mixing and entraining nutrient-rich waters. The depth of mixing determines the strength of seasonal particulate flux, nutrient concentrations and primary production during the subsequent spring bloom (Michaels and Knap, 1996; Steinberg et al., 2001). With the onset of seasonal stratification in late February-March, a spring bloom develops when phytoplankton biomass and particulate organic carbon standing stocks are maximal. As seasonal stratification intensifies, a nutrient-depleted, shallow surface mixed layer develops which is underlain by a subsurface chlorophyll maximum at approximately 80-100 m depth. Strong stratification in summer and autumn results in low vertical mixing that limits nutrient availability and primary production. Seasonal cooling in late autumn results in erosion and gradual deepening of the mixed layer, with renewed nutrient entrainment into the euphotic zone and an increase in primary production. Mesoscale physical variability in this area is the dominant method of nutrient transport (McGillicuddy et al., 1998). In particular, passage of cyclonic and mode water eddies may lead to nutrient entrainment which generates short-lived phytoplankton blooms and community restructuring (Wiebe and Joyce, 1992; Olaizola et al., 1993; McNeil et al., 1999; Letelier et al., 2000; Seki et al., 2001; Sweeny et al., 2003) which could, in turn, impact higher trophic levels such as planktonic foraminifera. In addition, these blooms often result in short-lived, episodic periods of enhanced export fluxes of 
labile organic material to depth (Conte et al., 1998, 2003, 2014).

\section{Materials and methods}

\subsection{The OFP sediment trap time series}

The OFP mooring is located at $31^{\circ} 50^{\prime} \mathrm{N}, 64^{\circ} 10^{\prime} \mathrm{W}$, about $55 \mathrm{~km}$ southeast of Bermuda at $4200 \mathrm{~m}$ water depth (Fig. 1). Three Mark VII Parflux sediment traps (McLane Labs, Falmouth, MA) are deployed at depths of 500, 1500 and $3200 \mathrm{~m}$. The traps $\left(0.5 \mathrm{~m}^{2}\right.$ surface area $)$ are programmed to collect a continuous bi-weekly time series of the particle flux. Collected samples were processed according to Conte et al. (2001) and split into <125, 125-500, 5001000 and $>1000 \mu \mathrm{m}$ size fractions. We analysed foraminifera in the 125-500 and 500-1000 $\mu \mathrm{m}$ size fractions of $1500 \mathrm{~m}$ trap samples collected during two time periods: 19982000 and 2008-2010 (109 samples total). We selected the two equivalent 2.5-year intervals a decade apart to generate a bi-weekly resolved time series which would enable assessment of seasonality as well as interannual variability. Our analyses focused on 11 species that fall within three general groupings: (i) surface-dwelling species living within the upper $50 \mathrm{~m}$ water column (Globigerinoides ruber var. white/pink Globigerinella siphonifera, Globigerinoides sacculifer), (ii) intermediate-dwelling species living in the $\sim 50-200 \mathrm{~m}$ depth range (Orbulina universa, Globigerinoides conglobatus, Neogloboquadrina dutertrei, Pulleniatina obliquiloculata) and (iii) deep-dwelling species (or species that are thought to calcify over a large depth range) living in the $\sim 100-800 \mathrm{~m}$ depth range (Globorotalia inflata, Globorotalia crassaformis, Globorotalia truncatulinoides, Globorotalia hirsuta). Our assignments of the depth habitats were based on measured species depth distributions and/or inferred distributions based on oxygen isotopic composition (Fairbanks et al., 1980; Anand et al., 2003). The temporal offset between the foraminiferal species fluxes reaching the trap at $1500 \mathrm{~m}$ depth versus the timing of these species' growth in overlying waters will vary depending on habitat depths and individual species' sinking rates (Takahashi and Bé, 1984). A surface-dwelling $G$. ruber living at $25 \mathrm{~m}$ depth may sink at $\sim 198 \mathrm{~m} \mathrm{day}^{-1}$, taking $\sim 7$ days to reach the $1500 \mathrm{~m}$ trap, whereas a more heavily calcified deeper-dwelling species such as $G$. inflata may sink $\sim 504 \mathrm{~m} \mathrm{day}^{-1}$, taking only $\sim 3$ days to reach the $1500 \mathrm{~m}$ trap. These fast sinking rates are much shorter than the typical lifespans of PF and are thus not anticipated to cause any offset between the hydrographic and sediment trap flux data (Honjo and Manganini, 1993).

On average, $\sim 440$ tests were counted in each sample fraction. To generate the flux data, counts of total and individual foraminifera species in the sample aliquots for each size fraction were converted to total counts per sample fraction and then the totals for the two fractions were combined (i.e. total planktonic foraminifera between 125 and $1000 \mu \mathrm{m}$ in size). Total counts were then scaled for the processing split (60\%) and converted to flux (tests $\mathrm{m}^{-2} \mathrm{~d}^{-1}$ ). PF flux data is available through www.pangaea.de.

\subsection{BATS and remote sensing data}

The BATS site $\left(31^{\circ} 40^{\prime} \mathrm{N}, 64^{\circ} 10^{\prime} \mathrm{W}\right)$ is located just south of the OFP mooring (Fig. 1). Monthly hydrographic and biogeochemical data collected by the BATS time series were obtained from the BATS website (http://bats.bios.edu). Mixed layer depth (MLD) was available from Lomas et al. (2013) and was calculated from CTD profiles using the variable sigma- $t$ criterion equivalent to a $0.2^{\circ} \mathrm{C}$ temperature change (Sprintall and Tomczak, 1992). The mesoscale eddy field was assessed using interpolated data on sea surface anomaly available from the CCAR Global Historical Gridded SSH Data Viewer (http://eddy.colorado.edu/ccar/ssh/hist_global_ grid_viewer).

\section{Total planktonic foraminiferal fluxes}

\subsection{In relation to other mass fluxes}

The seasonal cycle and interannual variability of the PF flux at $1500 \mathrm{~m}$ depth is highly correlated with that of the total mass, carbonate and organic carbon fluxes. All fluxes are strongly characterized by an abrupt spring maximum during February-April, which varies significantly on an interannual basis (Fig. 2). For example, the spring PF flux peak ranged from a low of 400 tests $\mathrm{m}^{-2}$ day $^{-1}$ in 2008 , coinciding with minimal spring mass fluxes, to a high of 900 tests $\mathrm{m}^{-2}$ day $^{-1}$ in 2009, coinciding with an extreme peak in spring mass fluxes. All fluxes typically drop to a minimum over the summer months (May-August) and remain low until the following spring bloom. During these minima, the PF flux generally amounts to $<200$ tests $\mathrm{m}^{-2}$ day $^{-1}$. In some years (e.g. 2009 and, to a lesser extent, 2008), the PF flux displays a smaller, but distinct second peak in the months September-October. This secondary autumn peak can also be seen in the mass flux and carbonate flux in 2009 but is absent in the organic carbon flux. Over the entire record, the correlation between $\mathrm{PF}$ flux and mass, carbonate and organic carbon flux is 0.65 , 0.64 and 0.55 , respectively.

\subsection{Relative to upper ocean hydrography}

In Fig. 3 we compare interannual variations in bi-weekly resolved total PF flux to $\sim$ monthly resolved changes in key upper ocean hydrographic parameters, measured at the BATS site. PF flux exhibits an inverse relationship with seasonal variations in SSTs and reaches a maximum when SST is coolest in January-March (Fig. 3a). Of note, is the particularly large and prolonged PF bloom in 2010, which coincided 

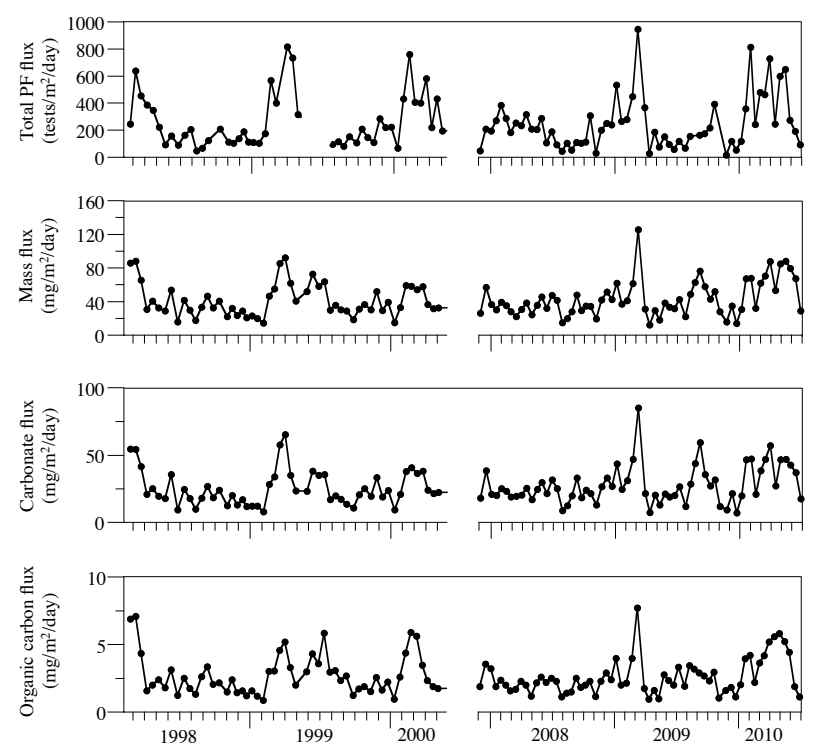

Figure 2. Temporal changes in total planktonic foraminifera flux and mass, carbonate, and organic carbon fluxes at $1500 \mathrm{~m}$ depth over the 6-year study period.

with a cyclonic eddy that passed through the area causing the lowest SSTs on record for this site $\sim 18.9^{\circ} \mathrm{C}$ (Fig. 3a-b).

Sea level anomaly (SLA) provides information about eddies passing through the area (Fig. 3b). A negative anomaly is associated with cyclonic eddies and a positive anomaly associated with anticyclonic and mode water eddies. The SLA data show that the particularly high and prolonged PF fluxes, total mass flux and organic carbon flux in spring 2009 and 2010 coincided with the passage of cold, cyclonic eddies (Fig. 2), which enhance nutrient upwelling into the euphotic zone.

The annual and interannual PF flux is in phase with the deepening and shoaling of the mixed layer depth (MLD) (Fig. 3c) and with chlorophyll $a$ concentrations (Fig. 3d). The seasonal PF flux maximum coincides with the chlorophyll $a$ maximum (which is used here as a proxy for the spring phytoplankton bloom) and the organic carbon flux from $200 \mathrm{~m}$, which represents organic carbon export from surface productivity (Fig. 3e), and the deepest MLD during FebruaryMarch. During April-May, the MLD shoals back towards the surface coinciding with decreasing chlorophyll $a$ concentrations and PF flux. The strong correlation between the seasonality in PF flux and that of primary production and export is demonstrated by the regressions between total PF flux and chlorophyll $a$ concentration (Fig. 4a) and the $1500 \mathrm{~m}$ mass flux (Fig. 4b). During the winter-spring period the magnitude of PF flux generally follows the evolution in MLD and is maximal when the MLD is maximal (Fig. 4c). However, when the mixed layer depth shoals to $<80 \mathrm{~m}$ during the low productivity period in late spring and summer, this correlation is not significant (Fig. 4d).
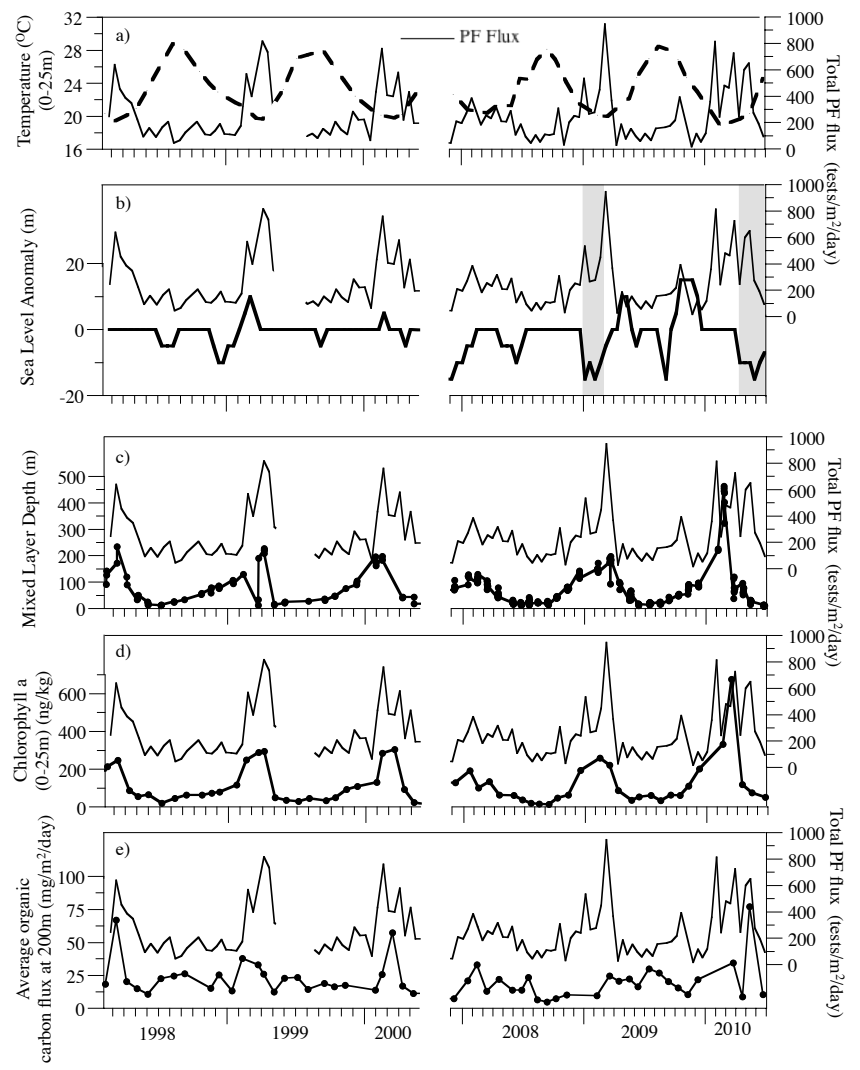

Figure 3. Temporal changes in environmental parameters measured at the BATS site in relation to total planktonic foraminiferal flux in the $1500 \mathrm{~m}$ OFP trap (thin, black line): (a) sea surface temperature (0-25 m), (b) sea level height anomaly; grey bars indicate periods when productive cyclonic eddies influenced the site, (c) mixed layer depth, (d) chlorophyll $a$ concentration (0-25 m average), and (e) average organic carbon flux at $200 \mathrm{~m}$.

\subsection{Planktonic foraminifera species fluxes}

In general, all planktonic foraminifera, and especially deeper-dwelling species, show strong, consistent seasonal variance (Figs. 5-7). Our results demonstrate a clear depth progression towards more pronounced seasonality in the deeper species, compared to a larger intra-seasonal variability in the surface and intermediate dwellers. In addition, the deep-dwelling PF species exhibit repeatable species successions throughout the winter and early spring (Fig. 8, Table 1). Figure 8 shows that Globorotalia truncatulinoides dominates the flux of deeper dwellers, and thrives each December, reaching a maximum during January. G. truncatulinoides is then followed by G. hirsuta, G. crassaformis, and G. inflata, which all peak between March and April. G. truncatulinoides displays large interannual variability (Table 1 ), ranging from lows of $\sim 4000$ tests $\mathrm{m}^{-2}$ year $^{1}$ in 2009-2010 to highs of up to $\sim 14000$ tests $^{-2}$ year $^{1}$ in 1999-2000 (Fig. 6). The remaining deeper dwellers (Globorotalia hirsuta, Globorotalia inflata, Globorotalia crassaformis) also 

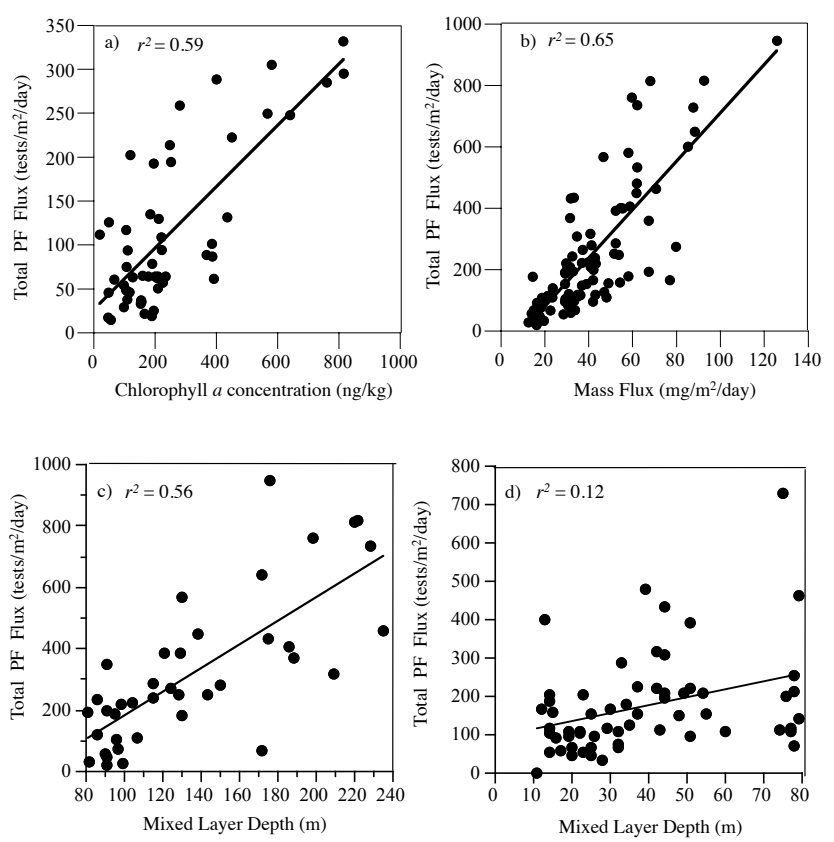

Figure 4. Correlation between total planktonic foraminifera flux in the $1500 \mathrm{~m}$ OFP trap (thin, black line) with environmental parameters measured at the BATS site. (a) Chlorophyll $a$ concentration at $0-25 \mathrm{~m}$. The correlation excludes an anomalous peak in chlorophyll $a$ concentration observed in 2010. (b) Regression with mass flux (c) MLDs $>80 \mathrm{~m}$, excluding the extremely deep MLD observed in 2010. (d) MLDs $<80 \mathrm{~m}$.

vary on an interannual basis. Figure 7 and Table 1 show that the largest fluxes of deeper-dwelling species occurred during the winter/spring of 1999-2000 and 2008-2009. Using shell weights from this study averaged with shell weights $(125-1000 \mu \mathrm{m})$ measured by Deuser (1987) and Deuser and Ross (1989), we estimate that PF flux contributes up to $\sim 40 \%$ of the total carbonate flux during winter-spring but $<10 \%$ during summer (Fig. 9a). Deeper-dwelling species account for 60-90\% of PF carbonate flux (Fig. 9b) and up to $37.5 \%$ of the total carbonate flux (e.g. during the winterspring of 2000) (Fig. 9c).

\section{Discussion}

The controls on PF flux in the Sargasso Sea was first introduced by Bé (1960) and later developed by Tolderlund and Bé (1971), who suggested that PF flux is dominantly controlled by the availability of their food phytoplankton. Thus, the environmental factors controlling PF flux should be closely aligned with the factors controlling phytoplankton productivity and export flux.
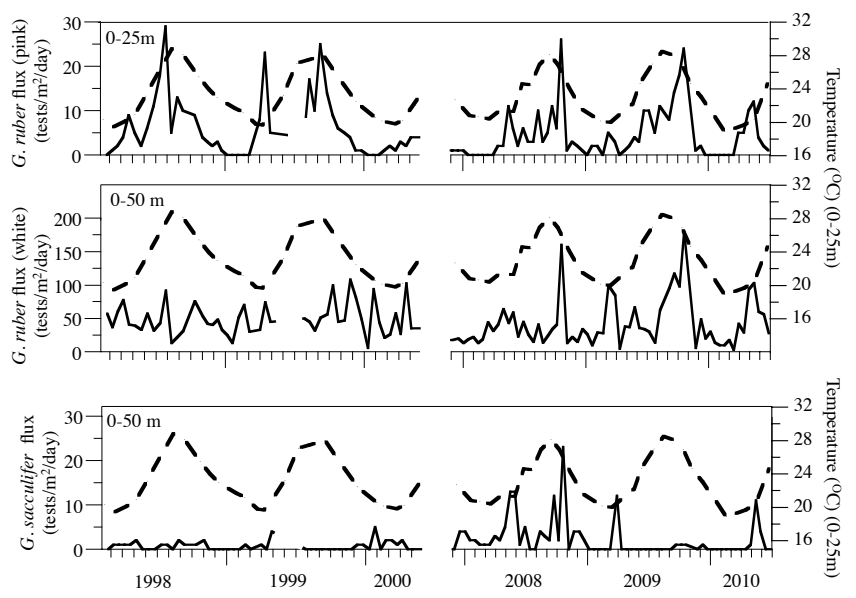

Figure 5. Temporal changes in surface-dwelling planktonic foraminifera fluxes in the $1500 \mathrm{~m}$ trap with changes in sea surface temperature (0-25 m) shown in the dashed black line for reference. The approximate depth habitat (Anand et al., 2003) is shown in figures.

\subsection{Environmental controls on PF fluxes}

\subsubsection{Depth of the mixed layer}

Previous studies suggest that increased chlorophyll concentrations and larger phytoplankton abundances occur when the MLD deepens (Townsend et al., 1994; Waniek, 2003; Nelson et al., 2004) and the amplitude and timing of MLD deepening determines the size of the following spring bloom (Menzel and Ryther, 1961; Michaels et al., 1994). Here, we also observe a simultaneous seasonal peak in chlorophyll $a$ and maximum depth of the MLD, as observed by previous studies at BATS (Steinberg et al., 2001; Cianca et al., 2012), the timing and amplitude of which coincides with the maximum PF flux (Fig. 3c, d). Similarly, seasonal changes in mixed layer depth are closely associated with changes in foraminifer production (Thunell and Reynolds, 1984; Sautter and Thunell, 1989; Pujol and Vergnaud Grazzini, 1995; Schmuker and Schiebel, 2002) and chlorophyll $a$ concentrations (King and Howard, 2003, 2005) in other ocean basins. Siegel et al. (2002) proposed that, south of $40^{\circ} \mathrm{N}$, the initiation and extent of the spring bloom is dominantly limited by nutrients, and this is supported by the simultaneous increase in phytoplankton concentrations with mixing depth at BATS (Treusch et al., 2012). Vertical mixing in late winter and spring distributes nutrients into the euphotic zone to support the spring phytoplankton bloom, causing the consequent seasonal peak in export fluxes of organic carbon, to fuel symbiont-barren foraminifera production (Fig. 2d). In contrast, no correlation exists between PF flux and MLD during the late spring to autumn when the mixed layer fails to penetrate the minimum depth of the deep chlorophyll maximum layer $(\sim 80 \mathrm{~m})$, where many species of planktonic foraminifera reside in association with other zooplankton and 
Table 1. Annual fluxes for planktonic foraminifera species at $1500 \mathrm{~m}$ depth in 1998-1999, 1999-2000, 2008-2009 and 2009-2010 and the 4-year averages. Fluxes were calculated from the sum of bi-weekly averages between July and June for each year and converted to tests $\mathrm{m}^{-2} \mathrm{yr}^{-1}$. Species are listed according to their estimated depth habitats.

\begin{tabular}{|c|c|c|c|c|c|c|c|}
\hline \multirow[b]{2}{*}{ Species } & \multirow[b]{2}{*}{ Seasonal flux maximum } & \multicolumn{5}{|c|}{ Annual flux (tests $\mathrm{m}^{-2} \mathrm{yr}^{-1}$ ) } & \multirow[b]{2}{*}{$\begin{array}{r}3200 \mathrm{~m} \text { avg } \\
(1978-1984)^{3}\end{array}$} \\
\hline & & 1998-1999 & 1999-2000 & 2008-2009 & 2009-2010 & Average & \\
\hline Surface dwellers: & & & & & & & \\
\hline G. ruber (pink) & Jul-Sept & 2524 & 1978 & 1576 & 2122 & 2050 & 1450 \\
\hline G. ruber (white) & Sept-Oct & 16197 & 19633 & 13917 & 18719 & 17117 & \\
\hline G. sacculifer & $\mathrm{Oct}^{1}, \mathrm{Mar}^{2}$ & 256 & 292 & 1007 & 348 & 1903 & 425 \\
\hline Surface totals & & 18977 & 21903 & 16500 & 21189 & 17346 & \\
\hline \multicolumn{8}{|l|}{ Intermediate dwellers: } \\
\hline G. siphonifera & 4 & 6101 & 3182 & 2231 & 2833 & 3587 & \\
\hline O. universa & Apr-May ${ }^{1}$, Oct-Nov ${ }^{2}$ & 1429 & 694 & 1056 & 2250 & 1357 & \\
\hline G. conglobatus & Nov & 277 & 180 & 0 & 4 & 115 & 300 \\
\hline N. dutertrei & Mar-Apr ${ }^{1}$, Nov-Dec ${ }^{2}$ & 1290 & 185 & 471 & 839 & 696 & 876 \\
\hline P. obliquiloculata & Dec-Mar & 398 & 205 & 708 & 352 & 416 & 762 \\
\hline Intermediate totals & & 9495 & 4446 & 4466 & 6278 & 6171 & \\
\hline \multicolumn{8}{|l|}{ Deep dwellers: } \\
\hline G. truncatulinoides & Jan-Feb & 5248 & 13796 & 9517 & 4031 & 8148 & 3420 \\
\hline G. hirsuta & Feb-Mar & 1784 & 9888 & 3859 & 2770 & 4575 & 1520 \\
\hline G. crassaformis & Feb-Mar & 26 & 100 & 122 & 139 & 97 & 192 \\
\hline G. inflata & Mar-Apr & 844 & 995 & 1652 & 1869 & 1340 & 1270 \\
\hline Deep totals & & 7902 & 24779 & 15150 & 8809 & 14160 & 5402 \\
\hline Other species & - & 51442 & 43704 & 43172 & 70446 & 51191 & \\
\hline Totals & - & 87816 & 94831 & 79289 & 106722 & 92165 & \\
\hline
\end{tabular}

${ }^{1}$ Primary peak. ${ }^{2}$ Secondary peak. ${ }^{3}$ Averages from Deuser and Ross (1989). ${ }^{4}$ This species has low seasonality.

algal cells (Fairbanks and Wiebe, 1980) (Fig. 4d). This is also the depth of the nitricline where nitrate concentrations are greater than $0.1 \mu \mathrm{mol} \mathrm{kg}^{-1}$ (Schiebel et al., 2001).

The majority of the increased PF flux in the winter-spring is driven by increased fluxes of deeper-dwelling species, in particular G. truncatulinoides and G. hirsuta (Fig. 9b). These species are symbiont-barren and rely on the flux of phytodetritus and other labile organic carbon as a food source from the spring phytoplankton bloom (Hemleben et al., 1989). The discrepancy in timing of peaks between the deeper-dwelling species (Fig. 8) is likely due to subtle changes in phytoplankton succession related to the species' diets (Deuser and Ross, 1989; Hemleben et al., 1989). Overall, the seasonal PF species succession is broadly similar to previous observations from 1959 to 1963 and 1978 to 1984 (Tolderlund and Bé, 1971; Deuser, 1987; Deuser and Ross, 1989) which suggests that, despite long-term environmental change, species seasonality have remained consistent over the past 50 years.

The correlation observed here between the seasonality in the PF flux, chlorophyll $a$ concentration and mass flux at $1500 \mathrm{~m}$ (Fig. 4a and b) clearly demonstrates that the seasonality of non-symbiont-bearing foraminifera, such as the globorotaliids, is controlled by phytoplankton production and the export flux of phytodetritus to depth. As these globorotaliids are up to 3 times denser than surface species (unpublished data), their sinking rates are significantly higher than those of other species. Thus, increased production by these species can accelerate the transfer of carbonate from surface to deep ocean, thereby strengthening the carbonate pump.

In contrast, the surface-dwelling symbiont-bearing foraminifera have lifecycles which strongly benefit from stratified surface waters and shallow mixed layers in order to photosynthesise - allowing them to succeed in low-nutrient conditions (Hemleben et al., 1989). Surface dwellers generally calcify in late summer when sea surface temperatures are at a maximum and dinoflagellates are abundant (Tolderlund and Bé, 1971). We thus conclude that the depth and structure of the mixed layer plays an important role in regulating PF species flux by controlling the abundance and timing of their food availability throughout the seasonal cycle.

\subsubsection{MLD deepening and shoaling rates}

Current models based on the light-limited higher latitudes (Waniek, 2003; Mao, Y., personal communication, 2013), suggest that if the MLD shoals early and slowly, the 

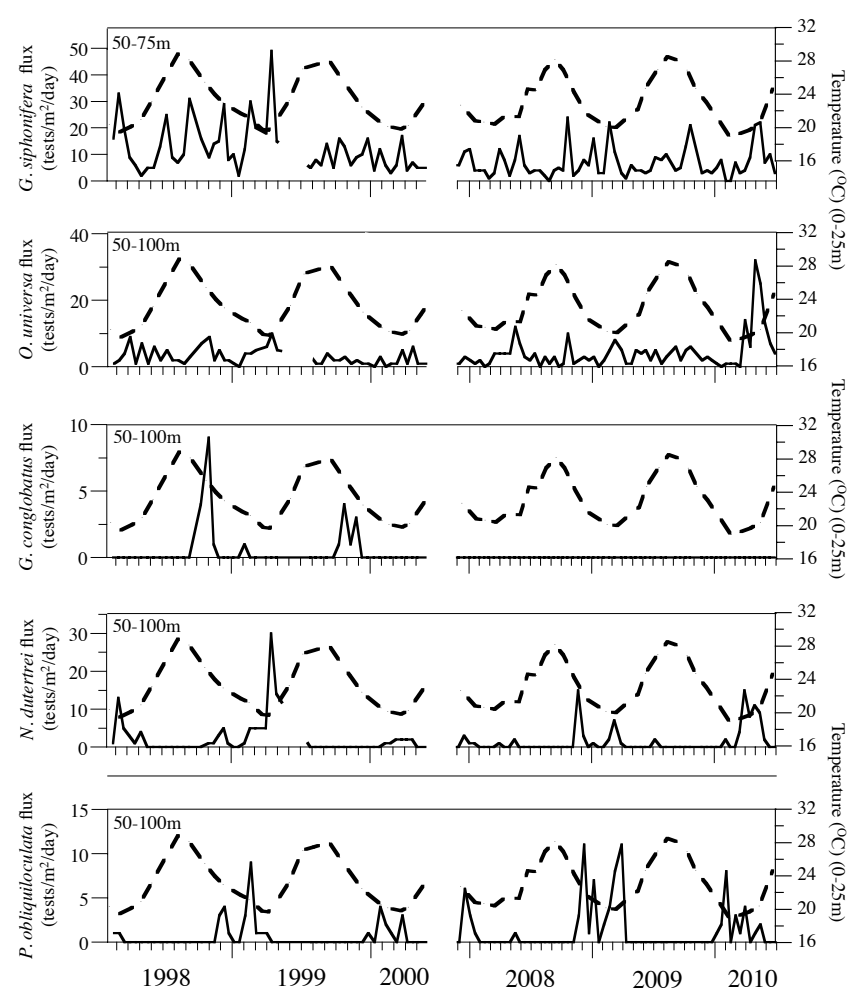

Figure 6. Temporal changes in intermediate-dwelling planktonic foraminifera fluxes in the $1500 \mathrm{~m}$ trap with changes in sea surface temperature (0-25 $\mathrm{m}$ ) for reference. The approximate depth habitat (Anand et al., 2003) is shown in figures.

consequent bloom will be long and weak compared to if the MLD shoals late and quickly, which causes a short and sharp bloom. At our subtropical study site, the spring bloom is predominantly limited by nutrient input into the euphotic zone, which is determined by the depth of the mixed layer. Increased heat loss and wind stress leading to higher convective mixing during the winter months controls the rate of deepening of the mixed layer, which is strongly correlated to the maximum MLD reached $\left(r^{2}=0.88\right)$ (Fig. 10a). Years with faster deepening rates have deeper mixed layers and hence larger spring blooms (e.g. winter 2009), whereas slow deepening rates cause shallower mixed layers and smaller spring blooms. There is also some evidence that light limitation could be a secondary control on the peak productivity of the spring bloom at this site (Dutkiewicz et al., 2001; Lomas et al., 2009; Cianca et al., 2012) as the euphotic zone extends to $\sim 100 \mathrm{~m}$ (Steinberg et al., 2001) and a faster shoaling rate during the spring could concentrate the food available for symbiotic foraminifera in the euphotic zone, resulting in a larger PF flux.

To test whether the rates of mixed layer deepening in early winter and of shoaling in spring affect the PF flux, we computed a mixed layer dynamics index, $D_{\mathrm{r}} / S_{\mathrm{r}}$, which is the ratio of the rate of deepening to the rate of shoaling, and
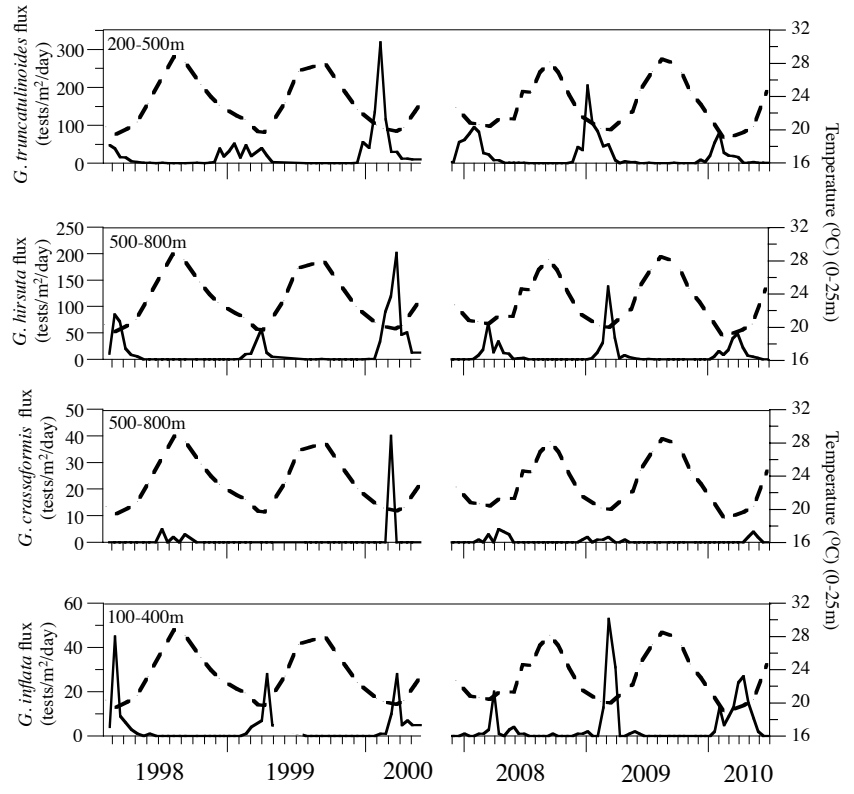

Figure 7. Temporal changes in deeper-dwelling planktonic foraminifera fluxes in the $1500 \mathrm{~m}$ trap with changes in sea surface temperature $(0-25 \mathrm{~m})$ for reference. The approximate depth habitat (Anand et al., 2003) is shown in figures. Graphs are ordered according to seasonal succession.

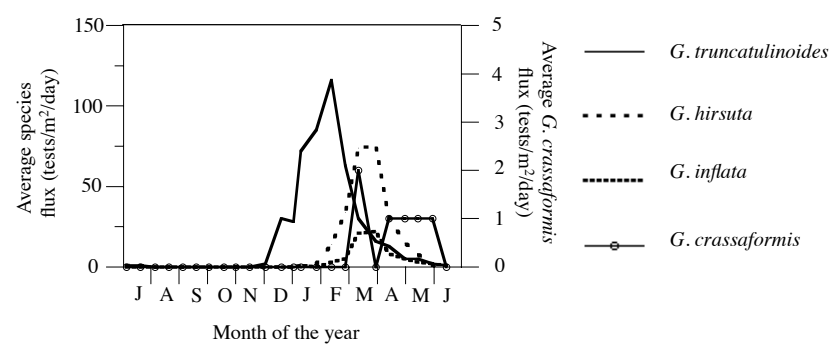

Figure 8. Seasonal succession for deeper-dwelling species averaged over six spring blooms $(1998,1999,2000,2008,2009,2010)$ from the $1500 \mathrm{~m}$ trap. G. truncatulinoides, G. hirsuta, and G. inflata appear on the left axis and G. crassaformis is on the right axis.

compared this to the integrated PF flux (Table 2). The $D_{\mathrm{r}} / S_{\mathrm{r}}$ ratio never exceeds 1 , indicating that the shoaling rate always exceeds the deepening rate. For all the years studied, there is a strong inverse relationship between the integrated $\mathrm{PF}$ flux over the duration of spring bloom, and the $D_{\mathrm{r}} / S_{\mathrm{r}}$ ratio (Fig. 10b, $r^{2}=0.93$ ). This relationship is also present in the maximum in chlorophyll $a$ concentration and the $D_{\mathrm{r}} / S_{\mathrm{r}}$ ratio (Figure $10 \mathrm{c}, r^{2}=0.76$ ). This correlation indicates that when the MLD shoals more quickly during spring stratification (lower $D_{\mathrm{r}} / S_{\mathrm{r}}$ ratio), the chlorophyll $a$ concentrations and PF flux are higher, as supported by a strong correlation $\left(r^{2}=0.87\right)$ between shoaling rate and integrated PF flux (Fig. 10d). 
Table 2. Mixed layer depth and mean rates of mixed layer (ML) deepening and shoaling. The $D_{\mathrm{r}} / S_{\mathrm{r}}$ ratio is a derived value calculated from the rate of ML deepening divided by the rate of ML shoaling (see text). The winter-spring PF flux represents the PF flux integrated over the whole bloom, which varied interannually in length but ranged from December to May. Bold faced years indicate years when a cyclonic eddy was present during the spring bloom period.

\begin{tabular}{|c|c|c|c|c|c|c|}
\hline Year & $\begin{array}{r}\text { MLD max } \\
(\mathrm{m})\end{array}$ & $\begin{array}{l}\text { ML deepening } \\
\text { rate }\left(\mathrm{m} \mathrm{day}^{-1}\right)\end{array}$ & $\begin{array}{l}\text { ML shoaling } \\
\text { rate }\left(\mathrm{m} \mathrm{day}^{-1}\right)\end{array}$ & $\begin{array}{r}D_{\mathrm{r}} / S_{\mathrm{r}} \text { ratio } \\
(\mathrm{m})\end{array}$ & 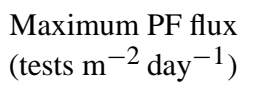 & $\begin{array}{l}\text { Integrated winter-spring } \\
\text { PF flux (tests } \mathrm{m}^{-2} \text { day }^{-1} \text { ) }\end{array}$ \\
\hline 1997-1998 & 235 & 0.93 & 1.91 & 0.49 & 641 & 28 \\
\hline 1998-1999 & 222 & 0.78 & 7.78 & 0.10 & 816 & 41 \\
\hline 1999-2000 & 197 & 0.63 & Data missing & - & 761 & 30 \\
\hline 2007-2008 & 130 & 0.55 & 0.75 & 0.73 & 385 & 17 \\
\hline 2008-2009 & 198 & 0.95 & 2.21 & 0.43 & 946 & 28 \\
\hline 2009-2010 & 464 & 1.76 & 3.82 & 0.46 & 815 & 32 \\
\hline
\end{tabular}

Years where the shoaling rate is twice as quick as the deepening rate (e.g. winters 1997, 2008, and 2009) have average $D_{\mathrm{r}} / S_{\mathrm{r}}$ ratios, average-length blooms and PF flux $\left(\sim 30\right.$ tests $\mathrm{m}^{-2} \mathrm{day}^{-1}$, Table 2$)$. Years with comparatively equal rates of shoaling and deepening (e.g. winter 2007) have larger $D_{\mathrm{r}} / S_{\mathrm{r}}$ ratios, longer and slower blooms with shallower MLDs and small PF fluxes. Years when the shoaling rate is much quicker than deepening rate (e.g. winter 1999) have the smallest $D_{\mathrm{r}} / S_{\mathrm{r}}$ ratios and shorter, sharper blooms with greater numbers of intermediate thermoclinedwelling species such as N. dutertrei, P. obliquiloculata, G. siphonifera, suggesting that when the rate of shoaling is higher the seasonal thermocline is nearer to the surface for longer, which is beneficial for these symbiont-bearing and symbiont-facultative species. The PF fluxes were large (and prolonged) respectively in winter 2008-2009 and 2009-2010 despite having average $D_{\mathrm{r}} / S_{\mathrm{r}}$ ratios but were probably enhanced by additional factors discussed in the next section.

\subsubsection{Eddies}

The negative sea level anomalies in spring of 2009 and 2010 indicate that the large (and in 2010 prolonged) PF fluxes in these years were clearly associated with the passage of cyclonic eddies (Fig. 3b). Eddy pumping of nitrate into the euphotic zone has been shown to significantly increase new production (Oschlies and Garçon, 1998; Oschlies, 2002). Cianca et al. (2007) estimate that eddy pumping contributes $\sim 50 \%$ of the nutrient input into the euphotic zone in the Sargasso Sea. Studies at the BATS site have demonstrated the influence of cyclonic and mode water eddies in promoting phytoplankton blooms and increased secondary production (Eden et al., 2009; McGillicuddy et al., 2007, 1999; Goldthwait and Steinberg, 2008; Sweeney et al., 2003; Lomas et al., 2013; Cianca et al., 2012) and therefore affecting PF food availability and quality (Schmuker and Schiebel, 2002). Previous studies have found higher fluxes of certain PF species such as Globigerinita glutinata associated with cyclonic eddy structures in the Caribbean Sea (Schmuker and Schiebel, 2002) and North Atlantic (Beckman et al.,
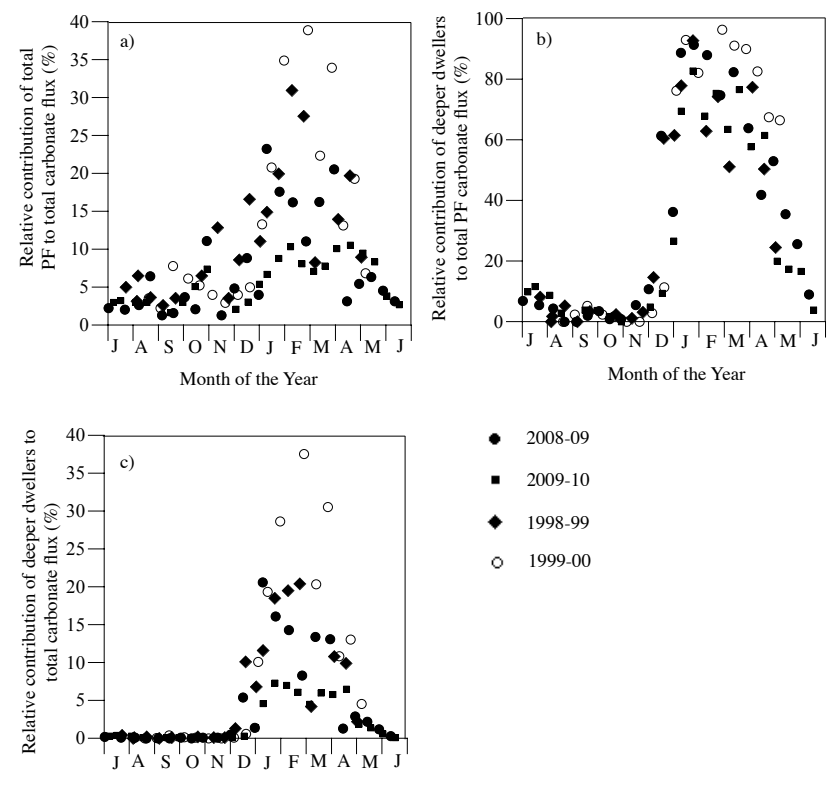

- 2008-09

- 2009-10

- 1998-99

- 1999-00

Figure 9. (a) The relative contribution of total PF to total carbonate flux (b) The relative contribution of deeper-dwelling planktonic foraminifera (G. hirsuta, G. truncatulinoides, G. crassaformis, G. inflata) to the total planktonic foraminiferal carbonate flux (c) The relative contribution of total deeper dwellers (G. hirsuta, G. truncatulinoides, G. crassaformis, G. inflata) to the total carbonate flux. All graphs show four full years 1998-1999, 1999-2000, 2008-2009 and 2009-2010.

1987), also in conjunction with upwelling frontal regions in the Mexican Pacific (Machain-Castillo et al., 2008) and deep mixed layers during winter in the Mediterranean (Pujol and Vergnaud Grazzini, 1995). Here we observe a similar response during the passage of a cyclonic eddy in spring 2009 , particularly for deeper-dwelling species. 


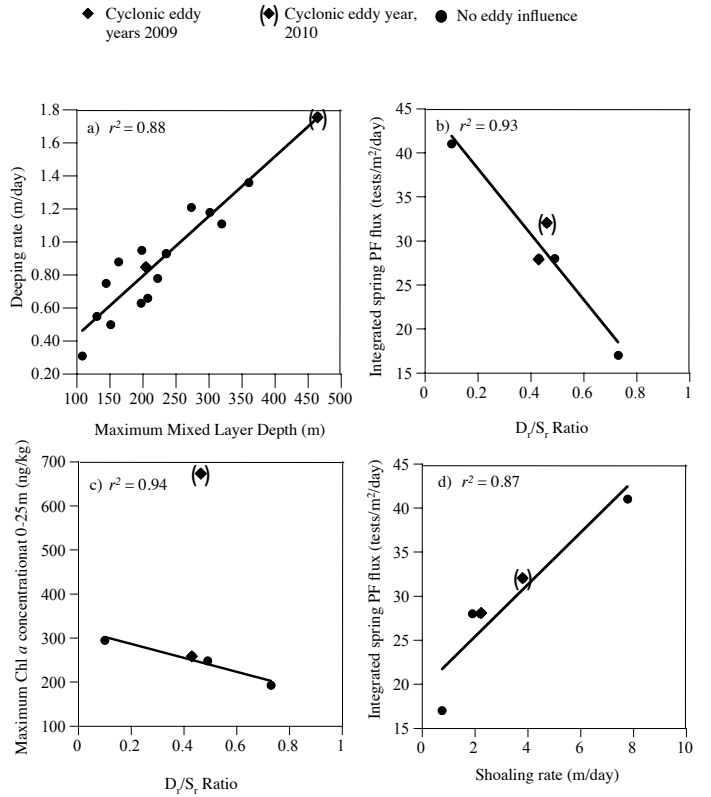

Figure 10. (a) Correlation between the maximum mixed layer depth and deepening rate of the mixed layer for years 1995-2011. (b) Correlation between the deepening: shoaling rate $\left(D_{\mathrm{r}} / S_{\mathrm{r}}\right)$ ratio of the mixed layer depth for all years studies excluding 2000 and integrated PF flux during the spring blooms which ranged from December to May, (c) maximum chlorophyll $a$ concentrations in the surface ocean during the spring bloom for all years studied, excluding the anomalous year 2010 in parentheses, (d) correlation between the shoaling rate and integrated flux of total PF over the spring bloom period which ranged from December to May. Diamonds indicate years with eddy influence 2009 and diamond with parentheses $=2010$. Round points are years without eddy influence.

In fact, the largest PF flux observed over the entire record was associated with this eddy passage, even though the maximum MLD and $D_{\mathrm{r}} / S_{\mathrm{r}}$ were modest (Table 2). Similarly, the mass and organic carbon flux measured during the passage of this eddy (Fig. 2b-d) were the highest fluxes measured over the last 25 years of the OFP time series, indicating that the conditions in this eddy promoted an extremely large export flux to fuel the production of deep-dwelling foraminifera species such as G. truncatulinoides, G. hirsuta, and especially $G$. inflata which all experienced higher seasonal fluxes in 2009 (Fig. 7).

This observation is consistent with an exceptionally large increase in the flux of $G$. truncatulinoides (>600 tests $\mathrm{m}^{-2} \mathrm{day}^{-1}$ ) seen at the OFP traps during the spring of 2007, which was also influenced by the passage of a productive cyclonic eddy (Fang et al., 2010; Conte and Weber, 2014). Both the 2007 and 2009 eddies occurred between January and March during the seasonal flux of the deeper dwellers (Fig. 7), underscoring the importance of the timing of eddy passage in enhancing PF flux. The influence of eddies here is similar to observations from the eastern

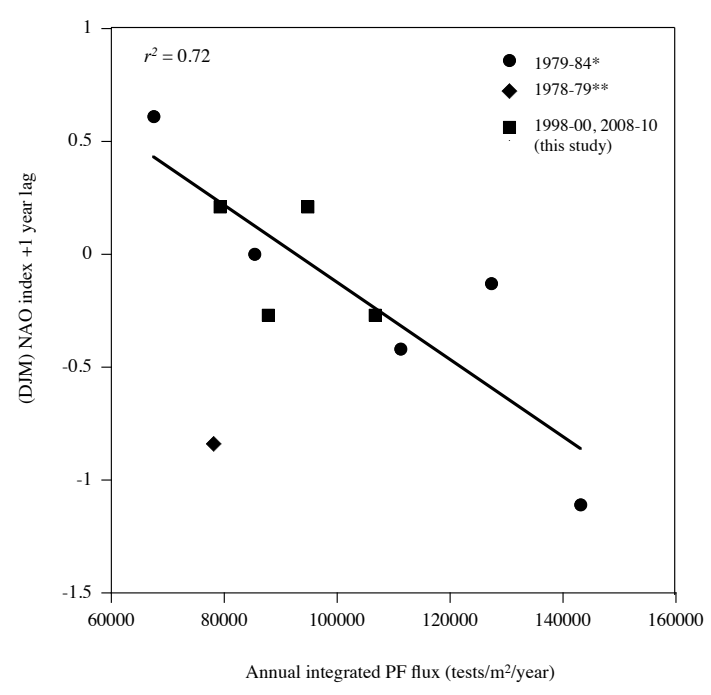

Figure 11. Annual integrated PF flux from this study (1500 m trap, square symbols) and 1979-1984 (*3200 m trap, round symbols, Deuser, 1987; Deuser and Ross, 1989) plotted against wintertime (DJFM) NAO index + 1-year lag. Annual fluxes from both trap depths are comparable. **Annual PF flux from 1978 (diamond symbol) was not included in the regression because it was an anomalously low flux year which could be explained by a shallow MLD and/or possibly the presence of an anticyclonic eddy (no data to test), which may have suppressed the spring bloom and hence PF flux as seen during 1994 at BATS (Lomas et al., 2013). NAO data available at http://www.cpc.ncep.noaa.gov/data/teledoc/nao.shtml.

Mediterranean where increased numbers of grazing species, such as $G$. truncatulinoides and $G$. inflata, have been found in association with eddy structures and deep mixed layers (Pujol and Vergnaud Grazzini, 1995). These findings suggest that productive cyclonic eddies, when co-occurring with deep MLDs, act to enhance the existing seasonal abundance of deeper-dwelling species through mixing of the water column, which aids their annual reproductive migration in addition to increasing food supply.

Along with the timing of the eddy passage, our observations also suggest that the PF flux response is dependent on whether the eddy is intensifying or weakening. For instance, both cyclonic eddies in 2009 and 2010 intensified over the spring bloom (Fig. 3b) eliciting a large biological response indicated by elevated subsurface $\mathrm{Chl} a$ concentrations and increased PF flux. In contrast, the cyclonic eddy in winter 2007-2008 was weakening over the spring bloom and therefore elicited no PF flux response.

Recent studies have found that eddies which are a minimum of 1-2 months in duration are more likely to induce a larger biological response (Mouriño-Carballido and McGillicuddy, 2006, Sweeny et al., 2003). Our observations also suggest that eddies need to be present for at least a month to elicit responses in the flux of $\mathrm{PF}$ which have minimum lifecycles of 2 weeks. For instance, in winter 1998-1999 a 
cyclonic eddy passed over the sediment trap site in only 1 month and elicited no biological response, compared to cyclonic eddies in 2009 and 2010, which both remained over the site for a minimum of 2-3 months and elicited large biological responses (Fig. 3b). These findings suggest that cyclonic eddies which intensify over the spring bloom and last for 1-3 months can elicit a significant biological response and increased PF flux.

\section{Implications}

Our results show that environmental factors and mesoscale eddy variability play an important role in regulating the planktonic foraminifera fluxes, by regulating the MLD and consequent magnitude of the spring bloom and biological export flux.

An overarching climatological variable affecting this region especially is the North Atlantic Oscillation (NAO), which exerts a strong influence on air temperature, storminess, heat loss, winter mixed layer depth, and, therefore, nutrient injection into the upper ocean during the winter months (Bates, 2012; Bates and Hansell, 2004; Rodwell et al., 1999). Modelling studies have shown that when the NAO is in its low phase, i.e. negative NAO (e.g. winter 2010), there is increased heat loss that intensifies convective mixing and results in enhanced nutrient upwelling into the euphotic zone to support primary production (Oschlies, 2001). The NAO influence on upper ocean productivity and biogeochemical fluxes is demonstrated by the inverse correlation between the wintertime (NDJF) NAO index and the deep particulate nitrogen flux in the OFP traps over a 30-year period (Conte and Weber, 2014) and increased primary productivity in negative wintertime NAO phases (Lomas et al., 2010). If convective mixing and nutrient entrainment into the euphotic zone is stronger during negative NAO years, this could serve to modulate PF flux, and therefore carbonate flux, on decadal timescales. When we compare PF fluxes covering a range of NAO indexes, from this study using the $1500 \mathrm{~m}$ trap to the $3200 \mathrm{~m}$ trap between 1978 and 1984 (Deuser and Ross, 1989; Deuser, 1987), we find a weak inverse correlation between total PF flux and (DJFM) NAO index in-phase (not significant), but we do find a significant inverse correlation with a (DJFM) NAO with a 1-year lag $(p<0.005)$ (Fig. 11). Cianca et al. (2012) showed that their correlation between winter NAO and total chlorophyll $a$ at BATS improved when applying a + 1-year time lag, but still remained insignificant. They attributed this to variability in the subtropical mode water, which can laterally advect nutrients on interannual timescales (Palter et al., 2005; Patara et al., 2011). We acknowledge that additional longer-term data are needed to test the mechanism behind this correlation, but our results suggest that changes in NAO status and/or mesoscale eddy frequency could significantly modulate planktonic foraminifera flux and export flux from the surface ocean on interannual timescales.

This study shows that the productivity of the dominant deep-dwelling species G. truncatulinoides and G. hirsuta is especially responsive to interannual variability in overlying surface water conditions and especially to the transient highproduction/flux events that are associated with the passage of productive cyclonic eddies that coincide with their seasonal spring production peak. Our data show that deeperdwelling species can account for up to $\sim 90 \%$ of the total PF carbonate flux, representing up to $\sim 40 \%$ of the total carbonate flux during winter-spring at the OFP site. Changes in NAO status, which modulates nutrient supply into the euphotic zone and the strength of the spring bloom, also may in turn modulate the production and flux of these heavily calcified deep-dwelling foraminifera by increasing their food supply, thereby intensifying the carbonate pump.

\section{Conclusions}

Our study demonstrates that the interannual variability in planktonic foraminifera flux can be linked to the MLD and the rate of deepening/shoaling of the mixed layer associated with nutrient injection into the euphotic zone. We find that higher PF fluxes coincide with deeper MLDs, especially when combined with cyclonic eddy-induced nutrient upwelling. In particular, the production of the dominant deep-dwelling species G. truncatulinoides and G. hirsuta is shown to be particularly responsive to interannual variability in overlying surface water conditions and especially to the transient high-production/flux events that are associated with productive cyclonic eddies. These species dominate the major late winter-early spring pulses of foraminifera and have higher sinking rates than surface-dwelling species because they are up to 3 times denser (unpublished results). We suggest deeper-dwelling species strengthen the carbonate pump by accelerating the transfer of carbonate from surface to deep ocean and contribute up to $40 \%$ of the contemporaneous peak in total carbonate export fluxes. It follows that any increase in fluxes of these deep dwellers arising from climateinduced changes in winter-spring mixed layer dynamics will also increase the average sinking rate of foraminiferal carbonate and intensify the overall carbonate pump. Our findings suggest that the North Atlantic Oscillation, via its influence on mixed layer depth, nutrient upwelling, phytoplankton production and export flux, may also serve to modulate the foraminiferal component of the carbonate pump in the subtropical North Atlantic. 
Acknowledgements. We would like to thank two anonymous reviewers for their time and constructive comments that helped improve the manuscript. This research was funded through the U.K. Ocean Acidification Research Program by Natural Environment Research Council grant to P. Anand and P. Sexton (grant NE/I019891/1). We acknowledge the National Science Foundation for its support of the Oceanic Flux Program time series (most recently by grant OCE-1234292) and the Bermuda Atlantic Time Series (most recently by grant OCE-0801991). We thank Mike Lomas for providing MLD data and Yolanda Mao for providing insights and useful discussion on the data. P. Anand is also thankful to Werner Deuser for communication regarding published data.

Edited by: J. Bijma

\section{References}

Anand P., Elderfield, H, and Conte, M. H.: Calibration of $\mathrm{Mg} / \mathrm{Ca}$ thermometry in planktonic foraminifera from a sediment trap time series, Paleoceanography, 18, 1050, doi:10.1029/2002PA000846, 2003.

Barker, S. and Elderfield, H.: Foraminiferal calcification response to Glacial-Interglacial changes in Atmospheric $\mathrm{CO}_{2}$, Science, 297, 833-836, 2002.

Bates, N. R.: Interannual variability of the oceanic $\mathrm{CO}_{2}$ sink in the subtropical gyre of the North Atlantic Ocean over the last 2 decades, J. Geophys. Res., 112, C09013, doi:10.1029/2006JC003759, 2007.

Bates, N. R.: Multi-decadal uptake of carbon dioxide into subtropical mode water of the North Atlantic Ocean, Biogeosciences, 9, 2649-2659, doi:10.5194/bg-9-2649-2012, 2012.

Bates, N. R. and Hansell, D. A.: Temporal variability of excess nitrate in the subtropical mode water of the North Atlantic Ocean, Mar. Chem., 84, 225-241, 2004.

Bates N. R., Pequignet, A. C., Johnson, R. J., and Gruber, N. A: short-term sink for atmospheric $\mathrm{CO}_{2}$ in the subtropical mode water of the North Atlantic Ocean, Nature, 420, 489-493, 2002.

Bé, A. W .H.: Ecology of Recent planktonic foraminifera, Part 2, Bathymetric and seasonal distributions off Bermuda, Micropaleontology, 4, 373-392, 1960.

Beckman, A., Auras, A., and Hemleben, C.: Cyclonic cold-core eddy in the eastern North Atlantic, 111, Zooplankton, Mar. Ecol. Prog. Ser., 39, 165-173, 1987.

Cianca, A., Helmke, P., Mouriño, B., Rueda, M.J., Llinás, O., and Neuer, S.: Decadal analysis of hydrography and in situ nutrient budgets in the western and eastern North Atlantic subtropical gyre, J. Geophys. Res., 112, C07025, doi:10.1029/2006JC003788, 2007.

Cianca, A., Godoy, J. M., Martin, J. M., Perez-Marrero, J., Rueda, M. J., Llinás, O., and Neuer, S.: Interannual variability of chlorophyll and the influence of low-frequency climate modes in the North Atlantic subtropical gyre, Global Biogeochem. Cy., 26, GB2002, doi:10.1029/2010GB004022, 2012.

CLIMAP Project Members: Climap 18k Database: IGBP PAGES/World Data Center-A for Paleoclimatology Data Contribution Series, v. 94-001, 1994,
Conte, M. H. and Weber, J. C.: Particle flux in the deep Sargasso Sea: The 35-year Oceanic Flux Program time series, Oceanography, 27, 142-147, 2014.

Conte, M. H., Weber, J. C., and Ralph, N.: Episodic particle flux in the deep Sargasso Sea: an organic geochemical assessment, Deep-Sea Res.-Pt. I, 45, 1819-1841, 1998.

Conte, M. H., Ralph, N., and Ross, E. H.: Seasonal and interannual variability in deep ocean particle fluxes at the Oceanic Flux Program (OFP)/Bermuda Atlantic Time Series (BATS) site in the western Sargasso Sea near Bermuda, Deep-Sea Res.-Pt. II, 48, 1471-1505, 2001.

Conte, M. H., Dickey, T. D., Weber, J. C., Johnson, R. J., and Knap, A. H.: Transient physical forcing of pulsed export of bioreactive organic material to the deep Sargasso Sea, Deep-Sea Res.-Pt. I, 50, 1157-1187, 2003.

Deuser, W. G.: Seasonal variations in isotopic composition and deep-water fluxes of the tests of perennially abundant planktonic foraminifera of the Sargasso Sea: Results from sediment-trap collections and their paleoceanographic significance, J. Foramin. Res., 17, 14-27, 1987.

Deuser, W. G. and Ross, E. H.: Seasonally abundant planktonic foraminifera of the Sargasso Sea: Succession, deep-water fluxes, isotopic composition, and paleoceanographic implications, J. Foramin. Res., 19, 268-293, 1989.

Deuser, W. G., Ross, E. H., and Anderson, R. F.: Seasonality in the supply of sediment to the deep Sargasso Sea and implications for the rapid transfer of matter to the deep ocean, Deep-Sea Res., 28A, 495-505, 1981.

Dutkiewicz, S., Follows, M., Marshall, J., and Gregg, W. W.: Interannual variability of phytoplankton abundances in the North Atlantic, Deep-Sea Res.-Pt. II, 48, 2323-2344, 2001

Eden, B. R., Steinberg, D. K., Goldthwait, S. A., and McGillicuddy, Jr, D. J. Zooplankton community structure in a cyclonic and mode-water eddy in the Sargasso Sea, Deep-Sea Res.-Pt. I, 56, 1757-1776, 2009.

Erez, J., Almogi-Labin, A., and Avraham, S. On the life history of planktonic foraminifera: lunar reproduction cycle in Globigerinoides sacculifer (Brady), Paleoceanography, 6, 295-306, 1991.

Fairbanks, R. G. and Wiebe, P. H.: Foraminifera and Chlorophyll Maximum: Vertical Distribution, Seasonal Succession, and Paleoceanographic Significance, Science, 209, 1524-1526, 1980.

Fairbanks, R. G., Wiebe, P. H., and Bé, A. W. Vertical distribution and isotopic composition of living planktonic foraminifera in the western North Atlantic, Science, 207, 61-63, 1980.

Fang, J., Conte, M. H., and Weber, J. C.: Influence of physical forcing on seasonality of biological components and deep ocean particulate flux in the Sargaddo Sea, Eos, Transactions American Geophysical Union 91, Ocean Sciences Meeting Supplement, Abstract BO24B-02, 2010.

Goldthwait, S. and Steinberg, D. K.: Elevated biomass of mesozooplankton and enhanced fecal pellet flux in cold-core and modewater eddies in the Sargasso Sea, Deep-Sea Res., 55, 1360-1377, 2008.

Hemleben, C., Spindler, M., Breitinger, I., and Deuser, W. G.: Field and laboratory studies on the ontogeny and ecology of some globorotaliid species from the Sargasso Sea off Bermuda, J. Foramin. Res., 15, 254-272, 1985.

Hemleben, C., Spindler, M., and Anderson, O. R.: Modern Planktonic Foraminifera, Springer, New York, 363 pp., 1989. 
Honjo, S. and Manganini, S. J.: Annual biogenic particle fluxes to the interior of the North Atlantic Ocean; studied at $34^{\circ} \mathrm{N} 21^{\circ} \mathrm{W}$ and $48^{\circ} \mathrm{N} 21^{\circ} \mathrm{W}$, Deep-Sea Res.-Pt. I, 40, 587-607, 1993.

King, A. L. and Howard, W. R.: Planktonic foraminiferal flux seasonality in Subantarctic sediment traps: A test for paleoclimate reconstructions, Paleoceanography, 18, 1019, doi:10.1029/2002PA000839, 2003.

King, A. L. and Howard W. R.: $\delta^{18} \mathrm{O}$ seasonality of planktonic foraminifera from Southern Ocean sediment traps: Latitudinal gradients and implications for paleoclimate reconstructions, Mar. Micropaleontol., 56, 1-24, 2005.

Kuroyanagi, A. and Kawahata, H.: Vertical distribution of living planktonic foraminifera in the seas around Japan, Mar. Micropaleontol., 53, 173-196, doi:10.1016/j.marmicro.2004.06.001, 2004.

Letelier, R. M, Karl, D. M., Abbott, M. R., Flament, P., Freilich, M., Lukas, R., and Strub, T.: Role of late winter mesoscale events in the biogeochemical variability of the upper water column of the North Pacific Subtropical Gyre, J. Goephys. Res., 105, 28 72328 740, Correction in J. Goephys. Res., 106, 7181-7182, 2000.

Lohmann, G. P. and Schweitzer, P. N.: Globorotalia truncatulinoides' Growth and chemistry as probes of the past thermocline: 1. Shell size, Paleoceanography, 5, 55-75, 1990.

Lomas, M. W., Lipschultz, F., Nelson, D. M., Krause, J. W., and Bates N. R.: Biogeochemical responses to late winter storms in the Sargasso Sea I - Pulses of primary and new production, Deep-Sea Res.-Pt. I, 56, 843-860, 2009.

Lomas, M. W., Steinberg, D. K., Dickey, T., Carlson, C. A., Nelson, N. B., Condon, R. H., and Bates, N. R.: Increased ocean carbon export in the Sargasso Sea linked to climate variability is countered by its enhanced mesopelagic attenuation, Biogeosciences, 7, 57-70, doi:10.5194/bg-7-57-2010, 2010.

Lomas, M. W., Bates, N. R., Johnson, R. J., Knap, A. H., Steinberg, D. K., and Carlson, C. A.: Two decades and counting: 24-years of sustained open ocean biogeochemical measurements in the Sargasso Sea, Deep-Sea Res.-Pt. II, 93, 16-32, 2013.

Lutz, B. P.: Shifts in North Atlantic planktic foraminifer biogeography and subtropical gyre circulation during the mid-Piacenzian warm period, Mar. Micropaleontol., 80, 125-149, 2011.

Machain-Castillo, M. L., Monreal-Gómez, M., Arellano-Torres, E., Merino-Ibarra, M., and González-Chávez, G.: Recent planktonic foraminiferal distribution patterns and their relation to hydrographic conditions of the Gulf of Tehuantepec, Mexican Pacific, Mar. Micropaleontol., 66, 103-119, 2008.

McGillicuddy, Jr., D. J., Robinson, A. R., Siegel, D. A., Jannasch, H. W., Johnson, R., Dickey, T. D., McNeil, J., Michaels, A. F., and Knap, A. H.: Influence of mesoscale eddies on new production in the Sargasso Sea, Nature, 394, 263-266, 1998.

McGillicuddy, Jr, D. J., Jonhson, R., Siegel, D. A., Michaels, A. F., Bates, N. R., and Knap, A. H.: Mesoscale variations of biogeochemical properties in the Sargasso Sea, J. Geophys. Res., 104, 13381-13394, 1999.

McGillicuddy D. J., Anderson, L., Bates, N. R., Bibby, T., Buesseler, K. O., Carlson, C. S., Davis, C., Ewart, P. G., Flakowski, S. A., Goldthwait, D., Hansell, Jenkins, W. J., Johnson, R., Kosnyrev, V. K., Ledwell, J., Li, Q., Siegel, D., and Steinberg, D. K.: Eddy/Wind interactions stimulate extraordinary mid-ocean plankton blooms, Science, 316, 1021-1025, 2007.
McNeil, J. D., Jannasch, H. W., Dickey, T., McGillicuddy, D., Brzezinski, M., and Sakamoto, C. M.: New chemical, bio-optical and physical observations of upper ocean response to the passage of a mesoscale eddy off Bermuda, J. Geophys. Res., 104, 15537-15548, 1999.

Menzel, D. W. and Ryther, J. H.: Annual variations in primary production of the Sargasso Sea off Bermuda, Deep-Sea Res., 7, 282 288, 1961.

Michaels, A. F. and Knap, A. H.: Overview of the U.S. JGOFS BATS and Hydrostation S program, Deep-Sea Res.-Pt. II, 43, 157-198, 1996.

Michaels A. F., Knap, A. H., Dow, R. L., Gundersen, K., Johnson, R. J., Sorensen, J., Close, A., Knauer, G. A., Lohrenz, S. E., Asper, V. A., Tuel, M., and Bidigare, R.: Seasonal patterns of ocean biogeochemistry at the U.S. JGOFS Bermuda Atlantic Timeseries Study site, Deep-Sea Res.-Pt. I, 41, 1013-1038, 1994.

Mouriño-Carballido, B. and McGillicuddy, D. J.: Mesoscale variability in the metabolic balance of the Sargasso Sea, Limnol. Oceanogr., 51, 2675-2689, 2006.

Nelson, N. B., Siegel, D. A., and Yoder, J. A.: The spring bloom in the northwestern Sargasso Sea: spatial extent and relationship with winter mixing, Deep-Sea Res.-Pt. II, 51, 987-1000, 2004.

Northcote, L. C. and Neil, H. L.: Seasonal variations in foraminiferal flux in the Southern Ocean, Campbell Plateau, New Zealand, Mar. Micropaleontol. 56, 122-137, 2005.

Olaizola, M., Ziemann, D. A., Bienfang, P. K., Walsh, W. A., and Conquest, L. D.: Eddy-induced oscillations of the pycnocline affect the floristic composition and depth distribution of phytoplankton in the subtropical Pacific, Mar. Biol., 116, 533-542, 1993.

Oschlies, A.: NAO-induced long-term changes in nutrient supply to the surface waters of the North Atlantic, Geophys. Res. Lett., 28, 1751-1754, 2001.

Oschlies, A.: Can eddies make ocean deserts bloom?, Global Biogeochem. Cy., 16, 1106, doi:10.1029/2001GB001830, 2002.

Oschlies, A. and Garçon, V.: Eddy-induced enhancement of primary production in a model of the North Atlantic Ocean, Nature, 394, 266-269, 1998.

Palter, J. B., Lozier, M. S., and Barber, R. T.: The effect of advection on the nutrient reservoir in the North Atlantic subtropical gyre, Nature, 437, 687-692, 2005.

Patara, L., Visbeck, M., Masina, S., Krahmann, G., and Vichi, M.: Marine biogeochemical responses to the North Atlantic Oscillation in a coupled climate model, J. Geophys. Res., 116, C07023, doi:10.1029/2010JC006785, 2011.

Pujol, C. and Vergnaud Grazzini, C.: Distribution patterns of live planktic foraminifers as related to regional hydrography and productive systems of the Mediterranean Sea, Mar. Micropaleontol., 25, 187-217, 1995.

Rodwell, M. J., Rowell, D. P., and Folland, C. K.: Oceanic forcing of the wintertime North Atlantic Oscillation and European Climate, Nature, 398, 320-323, 1999.

Sautter, L. and Thunell, R. C.: Seasonal succession of planktonic foraminifera: Results from a four-year time series sediment trap experiment in the northeast Pacific, J. Foramin. Res., 19, 253267, 1989.

Schiebel, R.: Planktic foraminiferal sedimentation and the marine calcite budget, Global Biogeochem. Cy., 16, 1065, doi:10.1029/2001GB001459, 2002. 
Schmuker B. and Schiebel, R.: Planktic foraminifers and hydrography of the eastern and northern Caribbean Sea, Mar. Micropaleontol., 46, 387-403, 2002.

Seki, M. P., Polovina, J. J., Brainard, R. E., Bidigare, R. R., Leonard, C. L., and Foley, D. G.: Biological enhancement at cyclonic eddies tracked with GOES thermal imagery in Hawaiian waters, Geophys. Res. Lett., 28, 1583-1586, 2001.

Sexton, P. F. and Norris, R. D.: Dispersal and biogeography of marine plankton: Long-distance dispersal of the foraminifer Truncorotalia truncatulinoides, Geology, 36, 899-902, 2008.

Sexton, P. F. and Norris, R. D.: High latitude regulation of low latitude thermocline ventilation and planktic foraminifer populations across glacial-interglacial cycles, Earth Planet. Sci. Lett., 311, 69-81, 2011.

Siegel, D. A., Doney, S. C., and Yoder, J. A.: The North Atlantic Spring, Phytoplankton Bloom and Sverdrup's Critical Depth Hypothesis, Science, 296, 730-733, 2002.

Storz, D., Schulz, H., Waniek, J. J., Schulz-Bull, D. E., and Kučera, M.: Seasonal and interannual variability of the planktic foraminiferal flux in the vicinity of the Azores Current, Deep-Sea Res.-Pt. I, 56, 107-124, 2009.

Spero, H. J.: Life history and stable isotope geochemistry of planktonic foraminifera, edited by: Norris, R. D. and Corfield, R. M., in: Isotope Paleobiology and Paleoecology, Paleontological Society Papers, Special Publication, 7-36, 1998.

Sprintall, J. and Tomczak, M.: Evidence of the barrier layer in the surface layer of the tropics, J. Geophys. Res.-Oceans, 97, 73057316, 1992.

Steinberg, D. K., Carlson, C. A., Bates, N. R., Rodney, J. J., Michaels, A. F., and Knap, A. H.: Overview of the US JGOFS Bermuda Atlantic Time-series Study (BATS): a decade-scale look at ocean biology and biogeochemistry, Deep-Sea Res.-Pt. II, 48, 1405-1447, 2001.

Sweeney E. N., McGillicuddy, Jr, D. J., and Buesseler, K. O.: Biogeochemical impacts due to mesoscale eddy activity in the Sargasso Sea as measured at the Bermuda Atlantic Time-series Study (BATS), Deep-Sea Res.-Pt. II, 50, 3017-3039, 2003.
Takahashi, K. and Bé, A. W. H.: Planktonic foraminifera: factors controlling sinking speed, Deep-Sea Res., 31, 1477-1500, 1984.

Thunell, R. C. and Reynolds, L. A.: Sedimentation of planktonic foraminifera: seasonal changes in species flux in the Panama Basin, Micropaleontology, 30, 243-262, 1984.

Tolderlund, D. S. and Bé, A. W. H.: Seasonal distribution of planktonic foraminifera in the western North Atlantic, Micropaleontology 17, 297-329, 1971.

Townsend, D. W., Cammen, L. M., Holligan, P. M., Campbell, D. E., and Pettigrew, N. R.: Causes and consequences of variability in the timing of spring phytoplankton blooms, Deep-Sea Res.-Pt. I, 41, 747-765, 1994.

Treusch, A. H., Demir-Hilton, E., Vergin, K. L., Worden, A. Z., Carlson, C. A., Donatz, M. G., Burton, R. M., and Giovannoni, S. J.: Phytoplankton distribution patterns in the northwestern Sargasso Sea revealed by small subunit rRNA genes from plastids, ISME Journal, 6, 481-492, 2012.

Waniek, J. J.: The role of physical forcing in initiation of spring blooms in the northeast Atlantic, J. Mar. Sys., 39, 57-82, 2003.

Wiebe, P. H. and Joyce, T.: Introduction to interdisciplinary studies of Kuroshio and Gulf Stream rings, Deep-Sea Res., 39, Supplement 1, 5-6, 1992.

Žarić, S., Donner, B., Fischer, G., Mulitza, S., and Wefer, G.: Sensitivity of planktic foraminifera to sea surface temperature and export production as derived from sediment trap data, Mar. Micropaleontol., 55, 75-105, 2005.

Zeebe, R. E., Bijma, J., Hoenisch, B., Sanyal, A., Spero, H. J., and Wolf-Gladrow, D. A.: Vital Effects and Beyond: A Modeling Perspective on Developing Paleoceanographic Proxy Relationships in Foraminifera, The Geological Society, London, Special Publications, in: Biogeochemical Controls on Palaeoceanographic Proxies, edited by: James, R., Austin, W. E. N., Clarke, L., and Rickaby, R. E. M., 303, 45-58, 2008. 